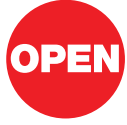

SUBJECT AREAS:

CHEMICAL SYNTHESIS

CHEMICAL BIOLOGY

DRUG DISCOVERY

CELL DEATH

Received

18 June 2012

Accepted

6 August 2012

Published

5 September 2012

Correspondence and requests for materials should be addressed to Y.P.P. (pang@mayo. edu for chemistry) or N.E.T. (tumer@aesop. rutgers.edu for biologyl

\section{Chemical Structure of Retro-2, a Compound That Protects Cells against Ribosome-Inactivating Proteins}

\author{
Jewn Giew Park' ${ }^{1}$ Jennifer Nielsen Kahn², Nilgun E. Tumer ${ }^{2} \&$ Yuan-Ping Pang'
}

'Computer-Aided Molecular Design Laboratory, Mayo Clinic, Rochester, MN 55905, USA, ${ }^{2}$ Department of Plant Biology and Pathology, School of Environmental and Biological Sciences, Rutgers University, New Brunswick, NJ 08901, USA.

Shiga-like toxins and ricin are ribosome-inactivating proteins (RIPs) that are lethal to mammals and pose a global health threat. No clinical vaccines or therapeutics currently exist to protect against these RIPs. Two small molecules (Retro-1 and Retro-2) were discovered with high-throughput screening and reported for their protection of cells against RIPs. Of great significance, Retro-2, reported as $(E)-2-(((5-$ methylthiophen2 -yl)methylene)amino)- $N$-phenylbenzamide, fully protected mice from lethal nasal challenge with ricin. Herein, we report studies showing that the chemical structure of Retro-2 is ( \pm )-2-(5-methylthiophen-2yl)-3-phenyl-2,3-dihydroquinazolin-4(1H)-one rather than (E)-2-((5-methylthiophen-2-yl)methylene) amino)- $N$-phenylbenzamide. The latter is an achiral molecule that converts spontaneously to the former, which is a racemate and showed cell protection against RIPs. This calls for attention to ( \pm )-2-(5-methylthiophen-2-yl)-3-phenyl-2,3-dihydroquinazolin-4( $1 H$ )-one as a promising RIP inhibitor and for chemical characterization of drug leads obtained from high-throughput screens.

higa-like toxins (Stx1 and Stx2) produced by certain strains of Escherichia coli are potent ribosomeinactivating proteins $(\mathrm{RIPs})^{1}$ responsible for outbreaks of foodborne disease with significant morbidity and mortality ${ }^{2}$. Ricin, produced by the castor plant Ricinus communis, is another potent RIP that has been used for both bioterrorism and the targeted killing of cancerous cells ${ }^{3}$. No US Food and Drug Administrationapproved vaccines or therapeutics currently exist to protect against ricin, Shiga-like toxins, or other RIPs.

Small-molecule inhibitors of ricin and Shiga-like toxins have been sought as potential therapeutics for preor post-exposure prophylaxis against RIP poisoning. Two small-molecule structures (Retro-1 and Retro-2; Figure 1) have been discovered with high-throughput screening for their cell protection against RIPs ${ }^{4}$. Of great significance, Retro- 2 at a concentration of $200 \mathrm{mg} / \mathrm{kg}$ demonstrated full protection of mice against a dose of ricin that killed $90 \%$ of an unprotected control mouse population ${ }^{4}$.

Using the doorstop approach in search of small-molecule RIP inhibitors that target the catalytic domain of the toxin $^{5}$, we synthesized Retro- 2 as a benchmark and found that the reported achiral Retro- 2 structure ${ }^{4}$ is unstable. Herein, we report our chemical syntheses and cell-based assays showing that the chemical structure of the compound that conferred cell protection activity against RIPs is Retro-2 $2^{\text {cycl }}$ (a racemic mixture; Figure 1 ). This raises a call for attention to Retro- $2^{\text {cycl }}$ as a promising RIP inhibitor and for chemical characterization of small molecules to be used in biological studies.

\title{
Results
}

Chemical structure analysis of Retro-2. Reaction of 2-amino- $N$-phenylbenzamide with 4-chlorobenzaldehyde in ethanol at room temperature with a catalytic amount of $p$-toluenesulfonic acid reportedly yielded IA4CL (a close analog of Retro-2; Figure 1$)^{6}$. No synthetic procedure has been reported for the commercially available Retro-2, and the vendor ChemBridge (San Diego, CA) provided Retro-2 for the reported biological study ${ }^{4}$. We obtained Retro- ${ }^{\text {cyc }}$ in $60 \%$ yield using the same reaction conditions reported for the synthesis of IA4CL, and found that these reaction conditions actually produced A4CL (a close analog of Retro-2 $2^{\text {cycl}}$; Figure 1). Evidence that Retro- $2^{\text {cycl }}$ rather than Retro-2 was the reaction product is found in the chemical shifts of two aliphatic carbon atoms (71.38 and $15.63 \mathrm{ppm}$ ) in the carbon NMR spectrum of Retro-2 $2^{\text {cycl }}$ because Retro-2 and Retro-2 $2^{\text {cycl }}$ have one and two aliphatic carbon atoms, respectively.

We also found that reacting 2-amino- $N$-phenylbenzamide with 5 -methylthiophene-2-carbaldehyde in acetic acid at room temperature produced Retro- $2^{\text {cycl }}$ exclusively in $88 \%$ yield. Interestingly, we found that stirring the 
<smiles>CCC(=O)N1CC(=O)Nc2ccc(Br)cc2[C@H]1c1ccccc1</smiles>

Retro-1<smiles>Cc1ccc(/C=N/c2ccccc2C(=O)Nc2ccccc2)s1</smiles>

Retro-2<smiles>Cc1ccc([C@@H]2Nc3ccccc3C(=O)N2c2ccccc2)s1</smiles>

Retro-2 ${ }^{\text {cycl }}$<smiles>O=C(Nc1ccccc1)c1ccccc1/N=C/c1ccc(Cl)cc1</smiles>

IA4CL<smiles>O=C1c2ccccc2N[C@H](c2ccc(Cl)cc2)N1c1ccccc1</smiles>

A4CL<smiles>Nc1ccccc1C(=O)Nc1ccccc1</smiles><smiles>Cc1ccc(C=O)s1</smiles><smiles>O=C(O)C1CCCCC1</smiles><smiles>Cc1ccc(/C=N/c2ccccc2C(=O)Nc2ccccc2)s1</smiles><smiles>CC(C)CC(C)C</smiles><smiles>Cc1ccc([C@@H]2Nc3ccccc3C(=O)N2c2ccccc2)s1</smiles>

Figure $1 \mid$ Chemical structures of Retro-2 and its analogs and a related synthetic scheme.

$t=144 h$

$t=120 \mathrm{~h}$ whll w

$t=96 h$

Mn Nu Nowlonen all w

$t=72 h$

Mon Nor Nowl Nom

uallat

Nowldnen

whentr

$t=48 h$

IMn Nax

Mwllo

$t=24 h$

Mun N N

lum all

$t=12 h$
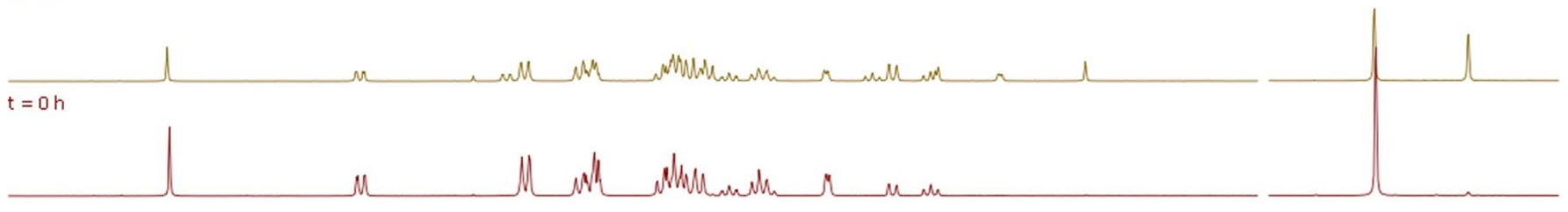

Figure $2 \mid$ Proton NMR spectra showing spontaneous conversion of Retro-2 to Retro-2 ${ }^{\text {cycl }}$ in neat deuterated methanol over 144 hours. 
two reactants in methanol for 1.5 hours at room temperature yielded Retro- $2^{\text {cycl }}$ and Retro-2. The latter has a chemical shift of only one aliphatic carbon atom (16.49 ppm) in the carbon NMR spectrum. Our proton NMR spectroscopic study showed that Retro-2 spontaneously converted to Retro- $2^{\text {cycl }}$ in neat deuterated methanol over a period of 144 hours, as indicated in Figure 2 by the gradual disappearance of the chemical shifts for the imine proton $(8.71 \mathrm{ppm})$ and the methyl proton (2.59 ppm) of Retro- 2 and the gradual and simultaneous appearance of the chemical shifts for the proton at the chiral center $(6.26 \mathrm{ppm})$ and the methyl proton $(2.34 \mathrm{ppm})$ of Retro- $2^{\text {cycl }}$. The half-life of Retro- 2 is $\sim 24$ hours in neat deuterated methanol (Figure 2). In the presence of a catalytic amount of acid, however, the conversion of Retro-2 to Retro- $2^{\text {cycl }}$ was completed within $\sim 30$ minutes.

More conclusively, we purchased Retro-2-listed as 2-\{[(5methyl-2-thienyl)methylene]amino $\}-N$-phenylbenzamide with ID 5374762 - from ChemBridge and found that the proton and carbon NMR spectra of the product we received were identical to those of Retro- $2^{\text {cycl }}$. These results indicate that Retro- 2 is unstable and spontaneously converts to Retro- $2^{\text {cycl }}$.

Cell-based assays of retro- $2^{\text {cycl }}$ and A4CL. To investigate whether Retro- $2^{\text {cycl }}$ is the actual chemical structure associated with cell protection against RIPs, we tested the cell-protection activities of Retro$2^{\text {cycl }}$ and A4CL using a $\left[{ }^{35} \mathrm{~S}\right]-$ Met-incorporation-based protein synthesis assay in Vero cells. As shown in Figure 3, the presence of $20 \mu \mathrm{M}$ Retro- $2^{\text {cycl }}$ moved the dose-response curve of protein synthesis in the presence of ricin or Stx 2 to increased Met incorporation, indicating cell protection by Retro- $2^{\text {cycl }}$ against ricin and Stx2. A4CL also showed cell protection against both toxins but was slightly less effective than Retro- $2^{\text {cycl }}$.

\section{Discussion}

The conversion of imines to 2,3-dihydroquinazolin-4(1H)-ones is well established in the literature ${ }^{7-11}$. The erroneous characterization of IA4CL rather than A4CL as the product of the reaction of 2amino- $N$-phenylbenzamide with 4-chlorobenzaldehyde in ethanol with a catalytic amount of $p$-toluenesulfonic acid was, in our view, probably due to the omission of the crucial carbon NMR spectrum ${ }^{6}$. The abundant literature information on 2,3-dihydroquinazolin$4(1 H)$-one synthesis and our synthetic work described above show unequivocally that Retro- 2 is unstable and spontaneously converts to Retro-2 ${ }^{\text {cycl }}$.

Given that the NMR spectra of Retro-2 from ChemBridge, which provided Retro- 2 for the reported biological studies ${ }^{4}$, are identical to those of Retro- $2^{\text {cycl }}$ and that Retro- $2^{\text {cycl }}$ and its structurally similar analog A4CL protect cells against ricin and Stx2, it is conceivable that Retro- $2^{\text {cycl }}$ - which is a racemate-is the compound responsible for the reported biological activities ${ }^{4}$. In this context, we measured the optical rotations of Retro-2 from ChemBridge and Retro- $2^{\text {cycl }}$ and found both to be zero. These results further support our assertion that a racemic mixture of Retro- $2^{\text {cycl }}$ produced the reported biological data $^{4}$.

We have previously reported caveats for the use of chemical screens for potential drug leads $s^{5,12}$. In a reported virtual screen for farnesyltransferase inhibitors ${ }^{12}$, we found that 6 of 27 compounds purchased from chemical vendors had serious chemical identity or purity issues. In another study of RIP inhibitors ${ }^{5}$, spectroscopic analyses required to confirm the stereochemistry of two chemicals revealed that the stereochemistry of one had been assigned incorrectly by the vendor. In the Retro- 2 report $^{4}$, of two promising chemical structures discovered with high-throughput screening, one appears to have been incompletely characterized by the chemical vendor. These repeated problems raise concerns and call for chemical characterization of leads identified from high-throughput screens.
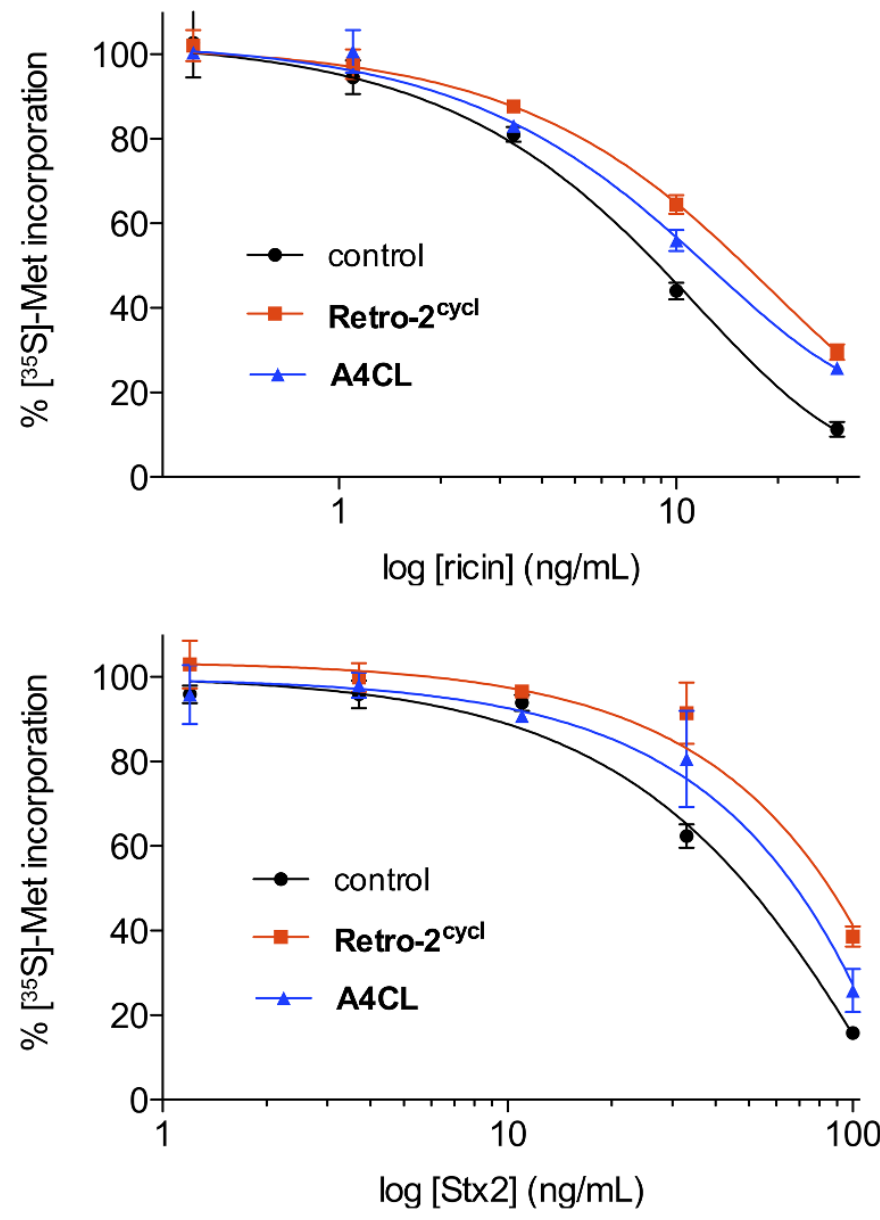

Figure $3 \mid$ Cell protection against ricin and Stx2 by Retro- $2^{\text {cycl }}$ and A4CL in Vero cells.

\section{Methods}

General description of chemical synthesis. All commercially available reagents were used as received. ${ }^{1} \mathrm{H}$ NMR $(400 \mathrm{MHz})$ and ${ }^{13} \mathrm{C}$ NMR $(100 \mathrm{MHz})$ spectra were recorded on a Mercury 400 spectrometer from Varian (Palo Alto, CA). Chemical shifts are reported in ppm using the solvent peak as an internal standard. Data are reported as follows: chemical shift, multiplicity $(\mathrm{s}=$ singlet, $\mathrm{d}=$ doublet, $\mathrm{t}=$ triplet, and $\mathrm{m}=$ multiplet), coupling constant, and integration. Low-resolution mass spectra (LRMS) were recorded using either a Hewlett Packard 5973 Mass Spectrometer with SIS Direct Insertion Probe (Palo Alto, CA) or a Waters ZQ/EMD 1000 Mass Spectrometer (Milford, MA). High-resolution mass spectra (HRMS) were obtained on a Bruker BioTOF II ESI. IR spectra were obtained on a ThermoNicolet Avatar 370 FT-IR (Waltham, MA) using a KBr pellet. A Biotage SP-1 (Charlotte, NC) was used for medium pressure liquid chromatography (MPLC) purification using silica gel as the packing material.

Synthesis of (E)-2-(((5-methylthiophen-2-yl)methylene)amino)- $\mathrm{N}$ phenylbenzamide (Retro-2). To a stirred solution of 2-amino- $N$-phenylbenzamide $(0.42 \mathrm{~g}, 2.00 \mathrm{mmol})$ in methanol $(6 \mathrm{~mL})$ at room temperature was added 5methylthiophene-2-cabaldehyde $(214 \mu \mathrm{L}, 2.00 \mathrm{mmol})$. After 1.5 hours of stirring, the reaction mixture was chilled to $-20^{\circ} \mathrm{C}$ for 1 hour. The resulting yellow short needles were collected via filtration, washed with methanol, and dried under high vacuum to give $0.35 \mathrm{~g}$ of yellow powder determined to be a $1: 1$ mixture of Retro-2 and Retro$2^{\text {cycl }}$ using ${ }^{1} \mathrm{H}$ NMR. The filtrate and washings were combined, concentrated in vacuo, purified with MPLC (silica gel, $100 \%$ hexanes to $30 \%$ EtOAc-hexanes) to give Retro-2 $(0.16 \mathrm{~g})$ as yellow viscous syrup and $0.11 \mathrm{~g}$ of a $1: 1$ mixture of Retro-2 and Retro$2^{\text {cycl }}$. The estimated yields of Retro- 2 and Retro- $2^{\text {cycl }}$ were $0.39 \mathrm{~g}(61 \%)$ and $0.23 \mathrm{~g}$ (36\%), respectively. Because Retro-2 (oil) was cyclized spontaneously to Retro- $2^{\text {cycl }}$ (solid), the spectral data were collected within 30 minutes after MPLC purification. ${ }^{1} \mathrm{H}$ $\operatorname{NMR}\left(400 \mathrm{MHz}, \mathrm{CDCl}_{3}\right) \delta 11.34(\mathrm{~s}, 1 \mathrm{H}), 8.47(\mathrm{~s}, 1 \mathrm{H}), 8.40(\mathrm{dd}, J=1.4,6.6 \mathrm{~Hz}, 1 \mathrm{H})$, $7.86(\mathrm{~d}, J=8.0 \mathrm{~Hz}, 2 \mathrm{H}), 7.58(\mathrm{~d}, J=7.8 \mathrm{~Hz}, 1 \mathrm{H}), 7.51-7.47(\mathrm{~m} 1 \mathrm{H}), 7.40-7.33(\mathrm{~m}$, $3 \mathrm{H}), 7.15-7.06(\mathrm{~m}, 2 \mathrm{H}), 6.85(\mathrm{~d}, J=3.3 \mathrm{~Hz}, 1 \mathrm{H})$, and $2.59(\mathrm{~s}, 3 \mathrm{H}) ;{ }^{13} \mathrm{C} \mathrm{NMR}$ $\left(100 \mathrm{MHz} \mathrm{CDCl}_{3}\right) \delta 164.24(\mathrm{C}=\mathrm{O}), 154.42(\mathrm{C}=\mathrm{N}), 148.95,148.52,139.64,138.95$, $135.67,132.90,131.84,129.25,129.11,127.57,126.97,124.10,120.82,118.98$, and 16.49; IR (KBr) v $3463(\mathrm{w}), 3346(\mathrm{w}), 3060(\mathrm{w}), 1659(\mathrm{~m}, \mathrm{C}=\mathrm{O}), 1608(\mathrm{~s}, \mathrm{C}=\mathrm{N})$, and $1538(\mathrm{~m}) \mathrm{cm}^{-1}$; LRMS-EI $m / z 320\left(\left[\mathrm{M}^{+}\right], 100 \%\right)$; HRMS-ESI $m / z 321.1050$ $\left([\mathrm{M}+\mathrm{H}]^{+}, \mathrm{C}_{19} \mathrm{H}_{17} \mathrm{~N}_{2} \mathrm{OS}^{+}\right.$requires 321.1062$)$. 
Synthesis of 2-(5-methylthiophen-2-yl)-3-phenyl-2,3-dihydroquinazolin-4(1H)one (Retro-2 $\left.{ }^{\text {cycl }}\right)$. Method 1: To a stirred solution of 2-amino- $N$-phenylbenzamide $(0.10 \mathrm{~g}, 0.48 \mathrm{mmol})$ and a few crystals of $p$-toluenesulfonic acid hydrate in ethanol $(3 \mathrm{~mL})$ was added 5-methylthiophene-2-cabaldehyde $(56.5 \mu \mathrm{L}, 0.52 \mathrm{mmol})$ at room temperature. Yellow precipitates appeared in 10 minutes; the color disappeared in 30 minutes. The precipitates were collected via filtration, and the filter cake was washed with ethanol and dried under high vacuum to give $0.093 \mathrm{~g}(60 \%)$ of Retro-2 ${ }^{\text {cycl }}$ as a grey powder. Method 2: To a stirred solution of 2-amino- $N$-phenylbenzamide $(0.21 \mathrm{~g}, 1.00 \mathrm{mmol})$ in acetic acid $(3 \mathrm{~mL})$ at room temperature was added 5 methylthiophene-2-cabaldehyde (107 $\mu \mathrm{L}, 1.00 \mathrm{mmol})$. Thin-layer chromatography showed completion of the reaction in 20 minutes. The solvent was removed in vacuo, and the crude product was purified with MPLC (silica gel, $100 \%$ hexanes to $30 \%$ EtOAc-hexanes) to give $0.28 \mathrm{~g}(88 \%)$ of Retro- $2^{\text {cycl }}$ as a pale yellow solid. The spectral data of Retro-2 ${ }^{\text {cycl }}$ prepared using methods 1 and 2 were identical. $\mathrm{mp} 152-154^{\circ} \mathrm{C} ;{ }^{1} \mathrm{H}$ $\operatorname{NMR}\left(400 \mathrm{MHz}, \mathrm{CDCl}_{3}\right) \delta 8.03(\mathrm{~d}, J=7.8 \mathrm{~Hz}, 1 \mathrm{H}), 8.02-7.23(\mathrm{~m}, 7 \mathrm{H}), 6.94(\mathrm{t}, J=$ $7.5 \mathrm{~Hz}, 1 \mathrm{H}), 6.70(\mathrm{~d}, J=8.2 \mathrm{~Hz}, 1 \mathrm{H}), 6.68(\mathrm{~d}, J=3.5 \mathrm{~Hz}, 1 \mathrm{H}), 6.47-6.46(\mathrm{~m}, 1 \mathrm{H})$, $6.20(\mathrm{~d}, J=2.3 \mathrm{~Hz}, 1 \mathrm{H}), 4.77(\mathrm{~s}, 1 \mathrm{H})$, and $2.36(\mathrm{~s}, 3 \mathrm{H}) ;{ }^{13} \mathrm{C} \mathrm{NMR}\left(100 \mathrm{MHz}, \mathrm{CDCl}_{3}\right) \delta$ $162.56(\mathrm{C}=\mathrm{O}), 145.14,141.24,140.93,140.71,134.07,129.28,129.25,127.21,127.09$, $126.82,124.58,120.33,117.50,115.58,71.38$, and 15.63; IR $(\mathrm{KBr}) \vee 3289(\mathrm{~m}, \mathrm{~N}-\mathrm{H})$, $1637(\mathrm{~s}, \mathrm{C}=\mathrm{O}), 1611(\mathrm{w}), 1505(\mathrm{~m}), 1486(\mathrm{~m})$, and $1387(\mathrm{~m}) \mathrm{cm}^{-1}$; LRMS-EI $m / z 320$ $\left(\left[\mathrm{M}^{+}\right], 100 \%\right)$; HRMS-ESI $m / z 321.1046\left([\mathrm{M}+\mathrm{H}]^{+}, \mathrm{C}_{19} \mathrm{H}_{17} \mathrm{~N}_{2} \mathrm{OS}^{+}\right.$requires 321.1062). Anal. cald for $\mathrm{C}_{19} \mathrm{H}_{16} \mathrm{~N}_{2} \mathrm{OS} 0.5 \mathrm{H}_{2} \mathrm{O}: \mathrm{C}, 69.28 ; \mathrm{H}, 5.20 ; \mathrm{N}, 8.50$. Found: $\mathrm{C}$, $69.43 ; \mathrm{H}, 5.23 ; \mathrm{N}, 8.61$

Conversion experiment of Retro-2 to Retro- ${ }^{\text {cycl }}$. A small amount ( $\left.\sim 2 \mathrm{mg}\right)$ of Retro-2 was dissolved in $\mathrm{CD}_{3} \mathrm{OD}(1.5 \mathrm{~mL})$, and ${ }^{1} \mathrm{H}$ NMR spectra were taken every 12 hours. The half-life of Retro- 2 to Retro- $2^{\text {cycl }}$ was $\sim 24$ hours at room temperature in $\mathrm{CD}_{3} \mathrm{OD}$.

$\left[{ }^{35} \mathrm{~S}\right]-$ Methionine incorporation assay. Vero cells were maintained in Dulbecco's modified Eagle medium with $10 \%$ fetal calf serum and $1 \mathrm{mM}$ glutamine. The cells were resuspended after trypsin treatment at $4 \times 10^{4}$ cells $/ \mathrm{mL}$ in the same medium, and $0.5 \mathrm{~mL}$ of the medium was dispensed into 24 -well plates. After 24 hours at $37^{\circ} \mathrm{C}$ and $5 \% \mathrm{CO}_{2}$, the medium was changed to Dulbecco's modified Eagle medium without Met, Gln, or fetal calf serum and equilibrated for 1 hour. An inhibitor solution with a final dimethyl sulfoxide concentration of $0.5 \%$ was added to the medium at 25 hours. Ricin or Stx 2 was added after 26 hours at varied concentrations. $\left[{ }^{35} \mathrm{~S}\right]$-Met was added 2 hours after ricin exposure or 3 hours after Stx 2 exposure. The $\left[{ }^{35} \mathrm{~S}\right]-\mathrm{Met}$ incorporation was terminated 30 minutes after the Met addition via medium removal and addition of $150 \mu \mathrm{L}$ of $0.2 \mathrm{M} \mathrm{KOH}$ to dissolve cells, as described elsewhere ${ }^{13}$. Proteins were precipitated with $10 \%$ trichloroacetic acid, harvested on glass fiber filters, and counted. The control incorporation was determined after treatment with $0.5 \%$ dimethyl sulfoxide alone. Ricin was purchased from Vector Laboratories (Burlingame, CA). Stx2 was provided by the Phoenix Laboratory (Tufts-NEMC Microbial Products \& Services Facility)

1. Johannes, L. \& Römer, W. Shiga toxins--from cell biology to biomedical applications. Nat Rev Microbiol 8, 105-116 (2010).

2. Snedeker, K. G., Shaw, D. J., Locking, M. E. \& Prescott, R. J. Primary and secondary cases in Escherichia coli O157 outbreaks: a statistical analysis. BMC Infect Dis $\mathbf{9}$, 144 (2009).

3. Audi, J., Belson, M., Patel, M., Schier, J. \& Osterloh, J. Ricin poisoning: a comprehensive review. JAMA 294, 2342-2351 (2005)
4. Stechmann, B. et al. Inhibition of retrograde transport protects mice from lethal ricin challenge. Cell 141, 231-242 (2010).

5. Pang, Y.-P. et al. Small-molecule inhibitor leads of ribosome-inactivating proteins developed using the doorstop approach. PLoS One 6, e17883 (2011).

6. Liang, Y., Su, B., Zhao, J. \& Sun, W. The synthesis of new asymmetric double shiff bases containing a new $\mathrm{O}$-amino benzoic acid derivative. Synth. Commun. 34, 3235-3242 (2004).

7. Wang, L.-M., Hu, L., Shao, J.-H., Yu, J. \& Zhang, L. A novel catalyst zinc(II) perfluorooctanoate $[\mathrm{Zn}(\mathrm{PFO}) 2]$-catalyzed three-component one-pot reaction: synthesis of quinazolinone derivatives in aqueous micellar media. J. Fluorine Chem. 129, 1139-1145 (2008).

8. Hisano, T., Ichikawa, M., Nakagawa, A. \& Tsuji, M. Studies on organosulfur compounds XII: syntheses and pharmacological activities of 2-heterocyclic substituted 4(3H)-quinazolinones. Chem. Pharm. Bull. 23, 1910-1916 (1975).

9. Sattarova, O. E., Vizgunova, O. L. \& Voronina, E. V. Synthesis and antimicrobial activity of 1,2-diaryl- and 2,3-diaryl-(2-aryl-3-N-arylamino)-1,2,3,4tetrahydroquinazolin-4-ones. Pharm. Chem. J. 40, 73-75 (2006).

10. Zhang, G. et al. Synthesis and crystal structure of a new quinazolinone compound 2,3-dihydro-2-(2-hydroxyphenyl)-3-phenyl-quinazolin-4(1H)-one. Chinese J. Struct. Chem. 24, 783-788 (2005).

11. Sattarova, D. E., Kozhevnikov, Y. V., Zalesov, V. S. \& Nikulina, S. N. Synthesis and biological activity of novel derivatives of 1,2,3,4-tetrahydroquinazolin-4-one. Khim.-Farm. Zh. 18, 1208-1210 (1984).

12. Perola, E. et al. Successful virtual screening of a chemical database for farnesyltransferase inhibitor leads. J. Med. Chem. 43, 401-408 (2000).

13. Jacewicz, M., Feldman, H. A., Donohue-Rolfe, A., Balasubramanian, K. A. \& Keusch, G. T. Pathogenesis of Shigella diarrhea. XIV. Analysis of Shiga toxin receptors on cloned HeLa cells. J. Infect. Dis. 159, 881-889 (1989).

\section{Acknowledgements}

This work was supported by the U.S. National Institute of Allergy and Infectious Diseases (1U01AI082120-01). We acknowledge Dr. Dengfeng Dou of the Computer-Aided Molecular Design Laboratory for developing a procedure to prepare Figure 2 in PDF using the MestReNov 7 program (Mestrelab Research, Spain).

\section{Author contributions}

J.G.P. discovered the conversion of Retro-2 to Retro-2 ${ }^{\text {crly }}$; Y.-P.P., J.G.P., and N.E.T. designed the experiments; J.G.P. and J.N.K. performed the experiments; all authors analyzed the data; Y.-P.P. wrote the paper; all authors contributed with revisions.

\section{Additional information}

Competing financial interests: The authors declare no competing financial interests.

License: This work is licensed under a Creative Commons

Attribution-NonCommercial-ShareAlike 3.0 Unported License. To view a copy of this license, visit http://creativecommons.org/licenses/by-nc-sa/3.0/

How to cite this article: Park, J.G., Kahn, J.N., Tumer, N.E. \& Pang, Y.-P. Chemical Structure of Retro-2, a Compound That Protects Cells against Ribosome-Inactivating Proteins. Sci. Rep. 2, 631; DOI:10.1038/srep00631 (2012). 